\title{
Phytotoxicity in two sugarcane cultivars in the initial development as affected by selectivity to herbicides
}

\section{Fitotoxidez em dois cultivares de cana-de-açúcar no desenvolvimento inicial em função da seletividade a herbicidas}

\author{
Ivonei Perego 1* (10) (https://orcid.org/0000-0003-4955-3258) \\ José Barbosa Duarte Júnior ${ }^{1}$ (D) (https://orcid.org/0000-0002-4297-5530) \\ Willian Bosquette Rosa' (iD (https://orcid.org/0000-0002-2642-5336) \\ Affonso Celso Gonçalves Júnior ${ }^{2}$ (D) (https://orcid.org/0000-0002-1699-1545) \\ Samara Brandão Queiroz' ${ }^{1}$ (D) (https://orcid.org/0000-0001-8542-2074) \\ Antônio Carlos Torres da Costa' (D) (https://orcid.org/0000-0002-3369-9642)
}

\begin{abstract}
Sugarcane is a crop of great importance for human consumption, either for the production of sucrose or for the production of ethanol fuel. The objective of this work was to evaluate the phytotoxicity caused by the herbicides, the agronomic components in two sugarcane cultivars, at five evaluation times, during the 12-month and 18-month cultivation periods. The experimental design was randomized blocks with four replicates, in a $10 \times 2$ factorial scheme, with nine herbicides (tembotrione, mesotrione, clomazone, saflufenacil, 2,4 dichlorophenoxyacetic, fluroxypyr + picloram, metribuzin, isoxaflutole, sulfentrazone), two sugarcane cultivars (RB006995 and RB036153), and five evaluation times (7, 14, 21, 28 and 35 days after application - DAA). The most phytotoxic herbicides for the 12-month cultivation period in the cultivars RB036153 and RB006995 were clomazone and sulfentrazone. For 18-month cultivation period, the herbicides isoxaflutole, clomazone and sulfentrazone were the most phytotoxic, mainly for the cultivar RB006995. For most herbicides, phytotoxicity decreased along the days after application. The most selective herbicides for both cultivars and cultivation periods were tembotrione, mesotrione and fluroxypyr + picloram.
\end{abstract}

KEYWORDS: phytotoxicity; Saccharum officinarum; sprouting; 12-month cultivation period; 18 -month cultivation period.
RESUMO: A cana-de-açúcar é uma cultura de grande importância para alimentação humana, tanto para a produção de sacarose quanto para a produção de combustível etanol. O objetivo deste trabalho foi avaliar a fitotoxidade causada pelos herbicidas, nos períodos de cultivo de cana de ano e cana de ano-e-meio durante o estádio de brotação e perfilhamento de dois cultivares de canade-açúcar. O delineamento experimental utilizado foi de blocos casualizados com quatro repetiçôes, em um esquema fatorial $10 \times 2$, sendo os fatores compostos por nove herbicidas (tembotriona, mesotriona, clomazona, saflufenacil, 2,4 diclorofenoxiacético, fluroxipir + picloram, metribuzin, isoxaflutol, sulfentrazona) mais uma testemunha, dois cultivares de cana-de-açúcar (RB006995, RB036153) e cinco épocas de avaliação (7, 14, 21, 28 e 35 DAA). Os herbicidas mais fitotóxicos para a cana de ano nos cultivares RB036153 e RB006995 foram clomazona e sulfentrazona. Para a cana de ano-e-meio, os herbicidas isoxaflutol, clomazona e sulfentrazona foram os mais fitotóxicos, principalmente no cultivar RB006995. Para a maioria dos herbicidas houve decréscimo da fitotoxidez com o passar dos dias após a aplicação. Os herbicidas mais seletivos para ambos os cultivares e períodos de cultivo foram tembotriona, mesotriona e fluroxipir + picloram.

PALAVRAS-CHAVE: fitotoxidez; Saccharum officinarum; brotação; cana-de-ano; cana-de-ano-e-meio.

\footnotetext{
'Universidade Estadual do Oeste do Paraná - Centro de Ciências Agrárias - Departamento de Fitotecnia - Marechal Cândido Rondon (PR) - Brazil. ${ }^{2}$ Universidade Estadual do Oeste do Paraná - Centro de Ciências Agrárias - Departamento de Química Ambiental e Instrumental - Marechal Cândido Rondon (PR) - Brazil. *Corresponding author: ivonei.agronomia@hotmail.com 


\section{INTRODUCTION}

Considering the use of chemicals in the main crops, soybean was in first place with $52 \%$, followed by maize and sugarcane with approximately $10 \%$, of the national total commercialized in 2015. In Brazil, 540,000 tons of phytosanitary products were used in 2017 , of which $58 \%$ corresponded to sales of herbicides, $12 \%$ to fungicides and $10 \%$ to insecticides (SINDIVEG, 2017).

Considering the chemical control method in the management of weed in the sugarcane crop, it is still necessary to expand the study of some herbicide molecules in relation to phytotoxicity caused to the crop. There are studies indicating that plant height is an intrinsic characteristic of each sugarcane cultivar and that all herbicides tested were selective for sugarcane (SOUZA et al., 2009).

After herbicide application, it is common to observe visual symptoms of phytotoxicity in the crop, but herbicide application does not always interfere with the production and technological quality of sugarcane. Application with herbicides in the crop have shown that atrazine and $\mathrm{S}$-metolachlor applied in postemergence of sugarcane are selective the crop, with 1.50 and $9.25 \%$ phytotoxicity, respectively, at 30 days after application (DAA) (GIROTTO et al., 2010).

The symptoms of phytotoxicity or damage to the agronomic components are due to an interference in plant metabolism, which differs according to the mechanism of action of the herbicide. The literature reports the action of some herbicide, such as metribuzin, which is the inhibition of photosystem II, through the binding of the atrazine molecule to the quinone- $\mathrm{B}$ binding site in $\mathrm{D} 1$ protein, stopping the electron flow between quinone A and B (TORRES et al., 2012).

The symptoms of phytotoxicity caused by herbicides in sugarcane plants usually decrease along the time after application, which has already been observed by SIMÓES et al. (2016). In this study, the electron transport rate showed recovery after 14 DAA, but the phytotoxicity caused by herbicides and the reduction in electron transport until 14 DAA did not interfere in stalk yield and technological quality of sugarcane.

There are differences regarding the susceptibility to herbicides depending on the cultivar planted, and it is appropriate to verify the susceptibility of the material used, which has already been observed in the genotypes RB72454 and RB835486, which were more affected than the others in the presence of trifloxysulfuron-sodium compared to the control, i.e. each cultivar has its own characteristics with regard to herbicide selectivity (GALON et al., 2013).

Application of herbicides in postemergence in sugarcane plants can cause phytotoxicity, which varies with the cultivar and cultivation period.

The objective of this study was to evaluate the effects caused by herbicides in terms of phytotoxicity in the 12-month and 18-month cultivation periods during the sprouting and tillering stage of two sugarcane cultivars.

\section{MATERIAL AND METHODS}

The experiment was conducted in a greenhouse, $24^{\circ} 33^{\prime} 28^{\prime \prime} \mathrm{S}$ latitude and 54 02' $44^{\prime \prime}$ W longitude, from March to July 2017 for the 18-month cultivation period and from September to December 2017 for the 12-month cultivation period. Meteorological data of air temperature were recorded with a datalogger and can be seen in Figures 1 and 2. Soil moisture was measured with a probe installed in the profile of two pots and kept close to field capacity, ensuring adequate moisture for plant development according to Figures 3 and 4 .

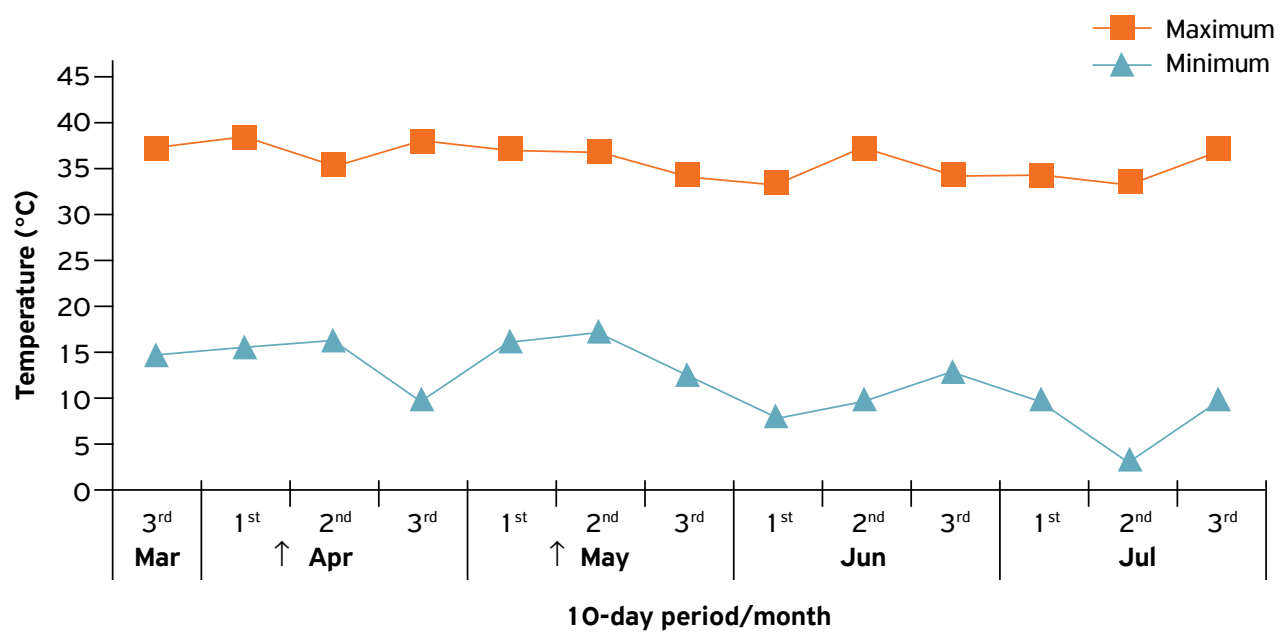

Figure 1. Maximum and minimum temperatures in 10-day periods from April to July 2017. 
The soil used as substrate was an eutroferric red latosol (oxisol), according to SANTOS et al. (2018), which was collected from the $0-20 \mathrm{~cm}$ layer and subjected to chemical analysis.

Soil chemical characteristics were: $\mathrm{P}=32.39 \mathrm{mg} \cdot \mathrm{dm}^{-3}$; $\mathrm{pH} \mathrm{CaCl}=5.53$; organic matter $(\mathrm{OM})=12.30 \mathrm{~g} \cdot \mathrm{dm}^{-3}$;

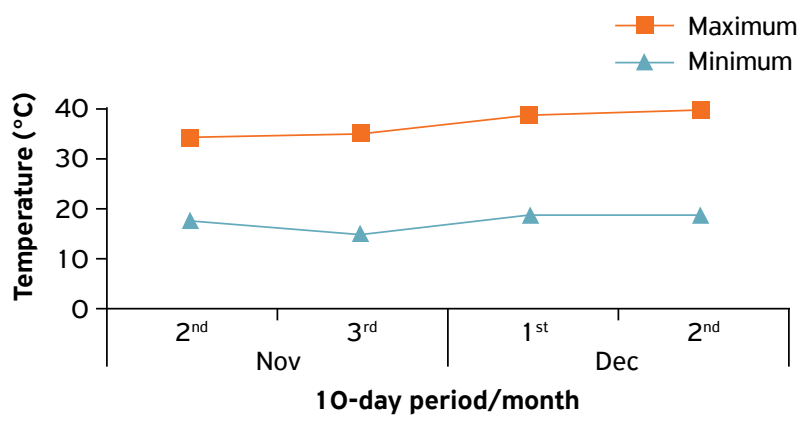

Figure 2. Maximum and minimum temperatures in 10-day periods from November to December 2017.
$\mathrm{H}+\mathrm{Al}=4.05 \mathrm{cmol}_{c} \cdot \mathrm{dm}^{-3} ; \mathrm{Al}^{3+}=0.00 \mathrm{cmol}_{c} \cdot \mathrm{dm}^{-3} ; \mathrm{K}=0.27 \mathrm{cmol}_{c} \cdot \mathrm{dm}^{-3}$; $\mathrm{Ca}^{2+}=3.47 \mathrm{cmol}_{\mathrm{c}} \cdot \mathrm{dm}^{-3} ; \mathrm{Mg}^{2+}=0.86 \mathrm{cmol}_{\mathrm{c}} \cdot \mathrm{dm}^{-3} ;$ cation exchange capacity $(\mathrm{CEC})=8.66 \mathrm{cmol}_{\mathrm{c}} \cdot \mathrm{dm}^{-3} ; \mathrm{Al}=0.00 \% ; \mathrm{V} \%: 53 \%$.

The soil substrate was prepared, being sieved, homogenized with a concrete mixer and limed using dolomitic limestone to increase base saturation to $70 \%$. Fertilization was performed with single superphosphate, potassium chloride and ammonium sulfate, respectively, raising the levels to: $\mathrm{P}=300 \mathrm{mg} \cdot \mathrm{dm}^{-3}$, $\mathrm{K}=150 \mathrm{mg} \cdot \mathrm{dm}^{-3}$ and $\mathrm{S}=40 \mathrm{mg} \cdot \mathrm{dm}^{-3}$ (ALVAREZ et al., 1991).

The experimental design used was randomized blocks, with four replicates in a $10 \times 2$ factorial scheme, with five split plots in time, consisting of the combination of nine herbicides (tembotrione, mesotrione, clomazone, saflufenacil, 2,4 dichlorophenoxyacetic, fluroxypyr + picloram, metribuzin, isoxaflutole, sulfentrazone) plus one control, two sugarcane cultivars (RB006995 and RB036153) and five evaluation times (7, 14, 21, 28 and 35 days after application).

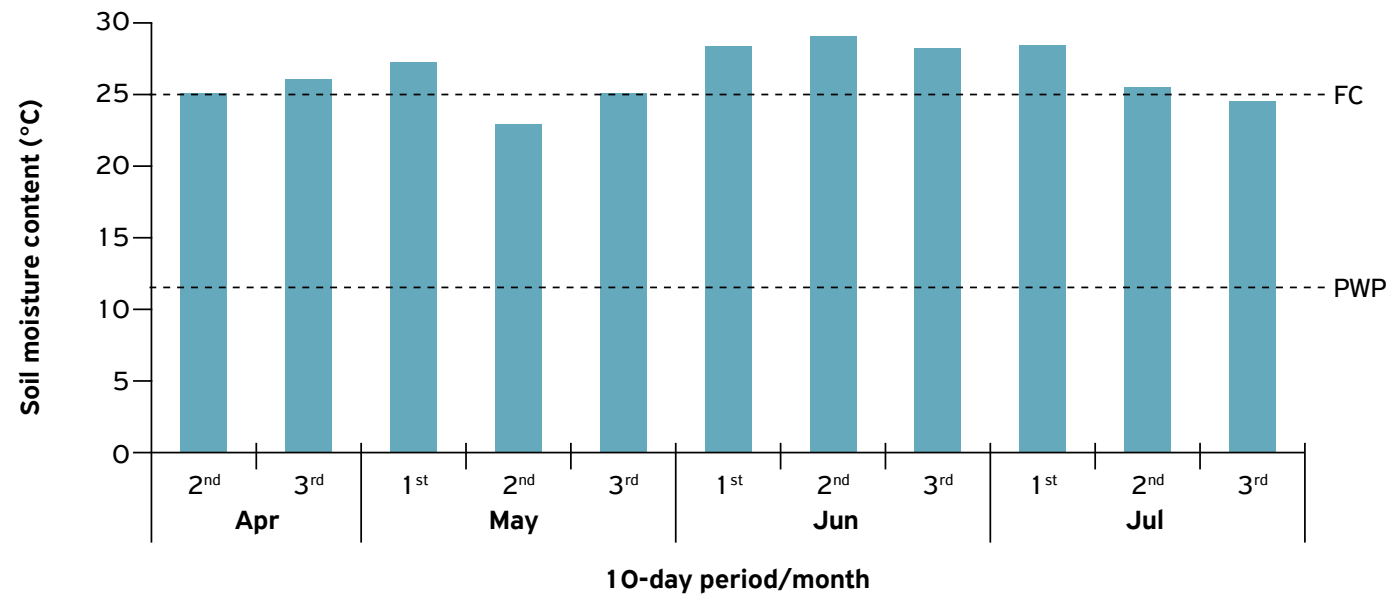

FC: field capacity; PWP: permanent wilting point

Figure 3. Soil moisture content in 10-day periods from April to July 2017.

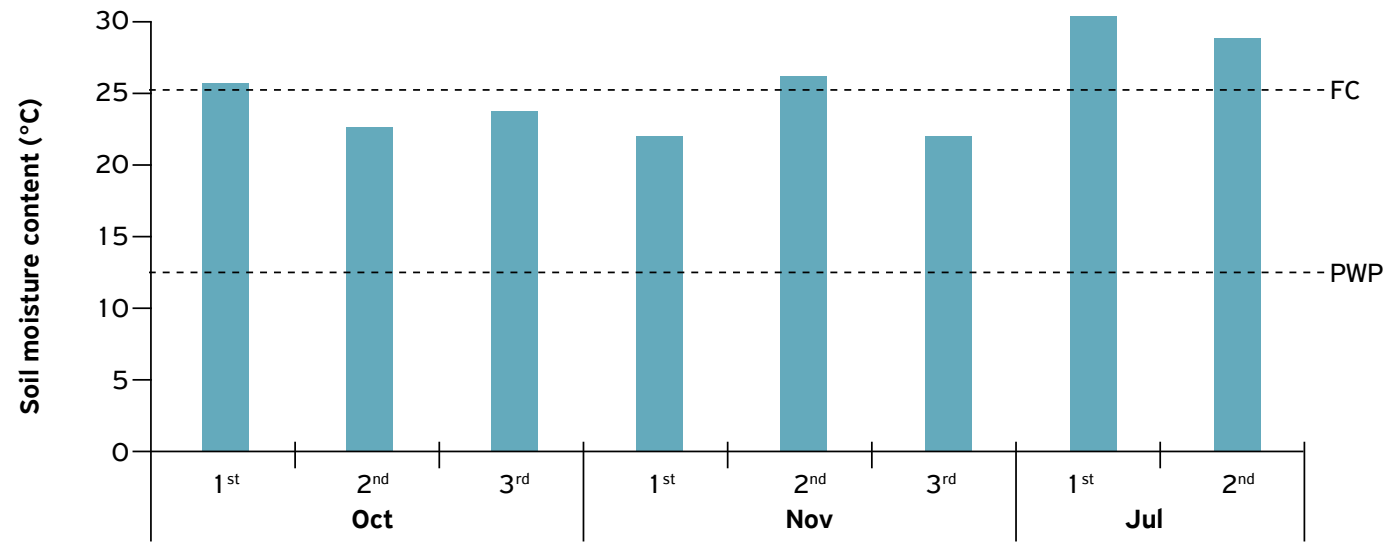

10-day period/month 
The sugarcane cultivar RB006995 is characterized by rapid initial growth, medium interrow closure, tall size, good tillering, semi-erect growth habit, high agricultural yield and sucrose content, tolerance to the main diseases and medium restriction regarding the requirement for environments, and maturity for harvest at the beginning of the season.

The cultivar RB036153 shows maturity for harvest in the middle of the season, good maturation curve, similar to that of cultivar RB867515, high rusticity, good adaptability and stability, and high stalk yield.

The commercial products used and their respective doses are presented in Table 1.

Herbicides were applied at 9:00 a.m., approximately 30 days after sprouting of the buds, in postemergence, in a period comprising the critical period to prevent interference of sugarcane. Application was carried out with a constant-pressure $\mathrm{CO}_{2}$-pressurized sprayer, calibrated with 32 psi pressure, equipped with 110.02 flat fan spray nozzles with flow rate

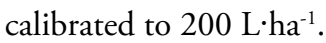

The experiment was installed in 7-L polypropylene pots filled with soil, spaced apart by $10 \mathrm{~cm}$. To install the experiment, the stalks were cut into single-budded setts, which were planted in the pots at a depth of 4 to $5 \mathrm{~cm}$ and covered with soil.

Weed management, despite the study of herbicide selectivity, was performed by manual uprooting. Management of diseases and pests was not necessary. The experiment was irrigated with the aid of a watering can, aiming to maintain the moisture content close to field capacity.

Phytotoxicity was quantified using a percentage score scale from 0 to 100 (VELINI et al., 1995), in which 0 corresponded to the absence of injury and 100 to plant death.

The data were subjected to analysis of variance by F-test at $5 \%$ probability level. In cases of significant effects, the means were compared by Tukey's test at $5 \%$ probability level. Regression analysis was performed for the evaluation times. Cultivation periods were compared using a joint analysis. The data met the assumptions of the ANOVA by the Shapiro-Wilk normality

Table 1. Commercial products, common names and doses used.

\begin{tabular}{lcc}
$\begin{array}{l}\text { Commercial } \\
\text { product }\end{array}$ & Common name & $\begin{array}{c}\text { Dose }(\text { a.i./ } \\
\left.\text { g a.e. } \cdot \text { ha }^{-1}\right)\end{array}$ \\
\hline Soberan & Tembotrione & 100.8 \\
\hline Callisto & Mesotrione & 144.0 \\
\hline Gamit & Clomazone & 1000.0 \\
\hline Heat & Saflufenacil & 49.0 \\
\hline 2,4 D Atanor & 2,4 dichlorophenoxyacetic & 967.2 \\
\hline Planador & Fluroxypyr + Picloram & $120+120$ \\
\hline Sencor & Metribuzin & 1440 \\
\hline Provence & Isoxaflutole & 75 \\
\hline Boral & Sulfentrazone & 600 \\
\hline
\end{tabular}

test. Statistical analyses were performed using the statistical software SAS University Edition (SAS, 2013).

\section{RESULTS AND DISCUSSION}

In the 18-month cultivation period in Figure 5, at $6 \mathrm{DAA}$ when the herbicide clomazone was applied in the cultivar RB006995, it caused phytotoxicity of $36 \%$, much higher when compared to the 12-month cultivation period in Figure 6, where the injuries were approximately $12 \%$ for this cultivar. For the cultivar RB036153 in Figures 7 and 8, when the herbicide clomazone was applied, there was phytotoxicity of $18 \%$ at $7 \mathrm{DAA}$, for the 12 -month cultivation period and $6 \%$ for 18 -month cultivation period.

\begin{tabular}{lll} 
Herbicide & \multicolumn{1}{c}{$\mathbf{R}^{2}$} & Equation \\
\hline Tembotrione & $0.99^{* *}$ & $\mathrm{Y}=23.2-1.8941 \mathrm{X}+0.0385 \mathrm{X}^{2}$ \\
\hline Mesotrione & $0.99^{* *}$ & $\mathrm{Y}=22.3725-15911 \mathrm{X}+0.029 \mathrm{X}^{2}$ \\
\hline Clomazone & $0.74^{* *}$ & $\mathrm{Y}=51.35-2.54847 \mathrm{X}+0.03899 \mathrm{X}^{2}$ \\
\hline Saflufenacil & $0.98^{* *}$ & $\mathrm{Y}=65.0134-5.6636 \mathrm{X}+0.1455 \mathrm{X}^{2}$ \\
\hline 2,4 dichlorophe- & $0.93^{* *}$ & $\mathrm{Y}=73.3066-6.7264 \mathrm{X}+0.1843 \mathrm{X}^{2}$ \\
noxyacetic & & \\
\hline Fluroxypyr + & $0.99^{* *}$ & $\mathrm{Y}=25.0168-2.6286 \mathrm{X}+0.069 \mathrm{X}^{2}$ \\
\hline Picloram & $0.77^{* *}$ & $\mathrm{Y}=42.15-2.10102 \mathrm{X}+0.03353 \mathrm{X}^{2}$ \\
\hline Metribuzin & & $\mathrm{Y}=34$ \\
\hline Isoxaflutole & & $\mathrm{Y}=32.15-0.08 \mathrm{X}$ \\
\hline Sulfentrazone & $0.63^{* *}$ & $\mathrm{Y}=0$ \\
\hline Control & & \\
\hline
\end{tabular}
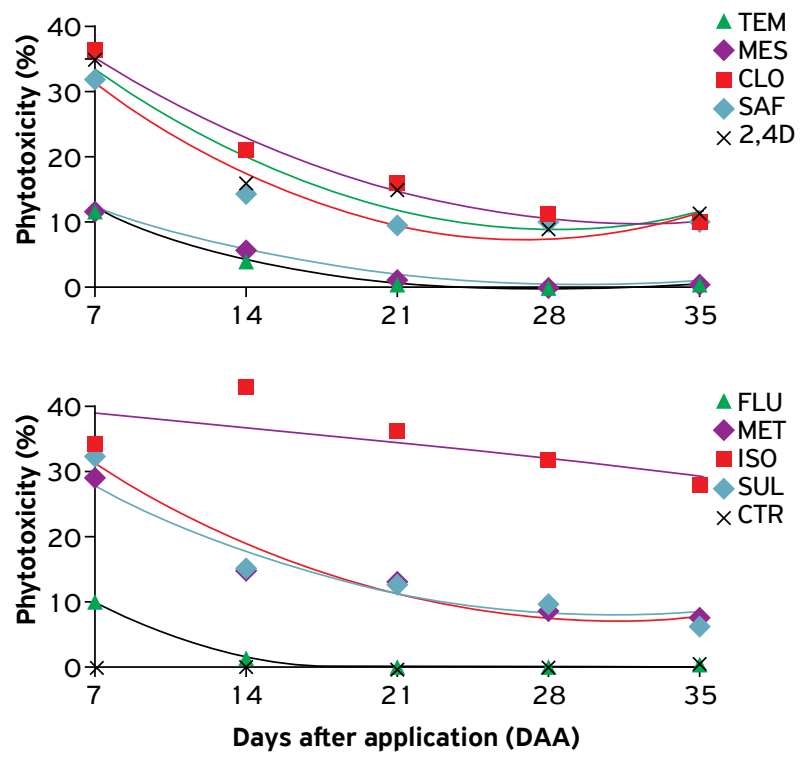

*significant at $5 \%$ probability level; ** significant at $1 \%$ probability level by Tukey test

Figure 5. Phytotoxicity as a function of evaluation times in the cultivar RB006995 under application of different herbicides, during the 18-month cultivation period. 
In the 12-month cultivation period, for the cultivar RB036153, when the herbicide sulfentrazone was applied, there was the highest phytotoxicity, reaching $19 \%$ at 7 DAA, with reduction to 11 and $9 \%$ at 21 and 35 DAA, respectively. In sugarcane plants subjected to the application of the herbicide clomazone, there was a reduction in phytotoxicity only from 28 DAA, reaching $14 \%$ at $35 \mathrm{DAA}$, with a linear behavior over time.

One possibility for the occurrence of more pronounced injuries in the 18-month cultivation period when compared to the 12-month cultivation period for both sugarcane cultivars evaluated was the occurrence of cloudy days after herbicide application in the 12-month cultivation period. A cause for higher phytotoxicity in treatments with the herbicide clomazone is the fact that it is indicated for application in preemergence or at the beginning of the sprouting of the ratoon cane.

\begin{tabular}{lll} 
Herbicide & $\mathbf{R}^{2}$ & Equation \\
\hline Tembotrione & & $\mathrm{Y}=0$ \\
\hline Mesotrione & $\mathrm{Y}=0.1$ \\
\hline Clomazone & $0.86^{* *}$ & $\begin{array}{l}\mathrm{Y}=-7.451 .3 .909001 \mathrm{X}+ \\
0.18477 \mathrm{X}^{2}-0.00243 \mathrm{X}^{3}\end{array}$ \\
\hline Saflufenacil & $0.72^{* *}$ & $\mathrm{Y}=2.75039-0.05981 \mathrm{X}+0.00267 \mathrm{X}^{2}$ \\
\hline $\begin{array}{l}\text { 2,4 dichlorophe- } \\
\text { noxyacetic }\end{array}$ & & $\mathrm{Y}=0.4$ \\
\hline $\begin{array}{l}\text { Fluroxypyr }+ \\
\text { Picloram }\end{array}$ & & $\mathrm{Y}=2.15$ \\
\hline Metribuzin & & $\mathrm{Y}=0.1$ \\
\hline Isoxaflutole & $0.50^{* *}$ & $\mathrm{Y}=-2.35-0.63622 \mathrm{X}+0.01421 \mathrm{X}^{2}$ \\
\hline Sulfentrazone & $0.81^{* *}$ & $\mathrm{Y}=14.975-0.25357 \mathrm{X}$ \\
\hline Control & & $\mathrm{Y}=0$ \\
\hline
\end{tabular}
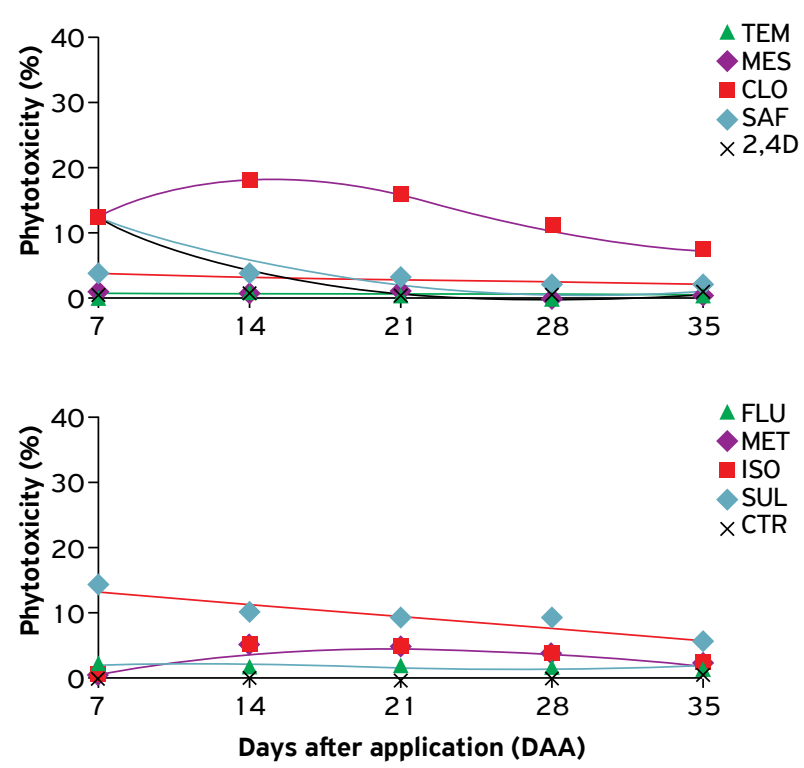

*significant at $5 \%$ probability level; **significant at $1 \%$ probability level by Tukey test

Figure 6. Phytotoxicity as a function of evaluation times in the cultivar RB006995 under application of different herbicides, during the 12-month cultivation period.
Results similar to those of the present study were found by SABBAG et al. (2017), who observed phytotoxicity levels of $24 \%$ caused by the herbicide clomazone at 7 DAA, but the phytotoxicity still remained at $25 \%$ at 60 DAA.

Likewise, SOARES et al. (2011) also found higher phytotoxicity caused by isoxaflutole, sulfentrazone and clomazone at 13 DAA when compared to the other herbicides. This is consistent with the results found by SILVA et al. (2013), who reported that the herbicide clomazone and diuron + hexazinone caused the highest intoxication in the plants at 14 DAA, reaching $40 \%$ phytotoxicity for the treatment with clomazone without fertilization. GALON et al. $(2009,2013)$ found different levels of phytotoxicity according to cultivars, equal to $11 \%$ in the cultivar RB855113 and to $5 \%$ in the cultivar RB947520, at 14 DAA.

\begin{tabular}{lll} 
Herbicide & $\mathbf{R}^{2}$ & Equation \\
\hline Tembotrione & & $\mathrm{Y}=0$ \\
\hline Mesotrione & $\mathrm{Y}=0.1$ \\
\hline Clomazone & $\mathrm{Y}=17.4$ \\
\hline Saflufenacil & $\mathrm{Y}=0.8$ \\
\hline $\begin{array}{l}\text { 2,4 dichlorophe- } \\
\text { noxyacetic }\end{array}$ & $0.71^{* *}$ & $\mathrm{Y}=3-0.05714 \mathrm{X}$ \\
\hline $\begin{array}{l}\text { Fluroxypyr }+ \\
\text { Picloram }\end{array}$ & & $\mathrm{Y}=1.5$ \\
\hline Metribuzin & & $\mathrm{Y}=0.1$ \\
\hline Isoxaflutole & $0.69 * *$ & $\mathrm{Y}=5.55+1.05306 \mathrm{X}+0.02405 \mathrm{X}^{2}$ \\
\hline Sulfentrazone & $0.71^{* *}$ & $\mathrm{Y}=0.00911 \mathrm{X}^{2}-0.70051 \mathrm{X}+23.45$ \\
\hline Control & & $\mathrm{Y}=0$ \\
\hline
\end{tabular}
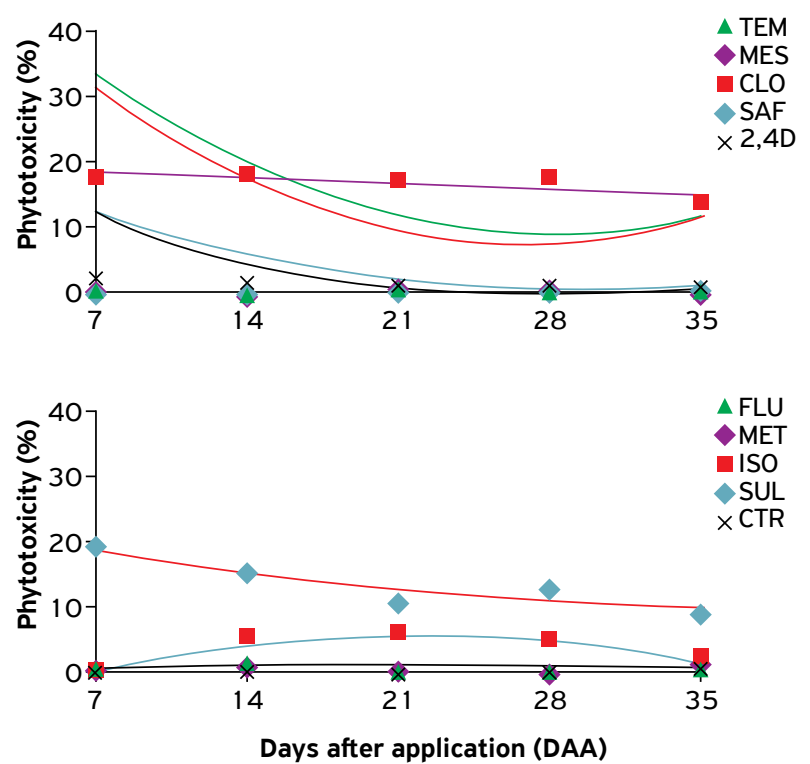

*significant at $5 \%$ probability level; * significant at $1 \%$ probability level by Tukey test

Figure 7. Phytotoxicity as a function of evaluation times in the cultivar RB036153 under application of different herbicides, during the 12-month cultivation period. 


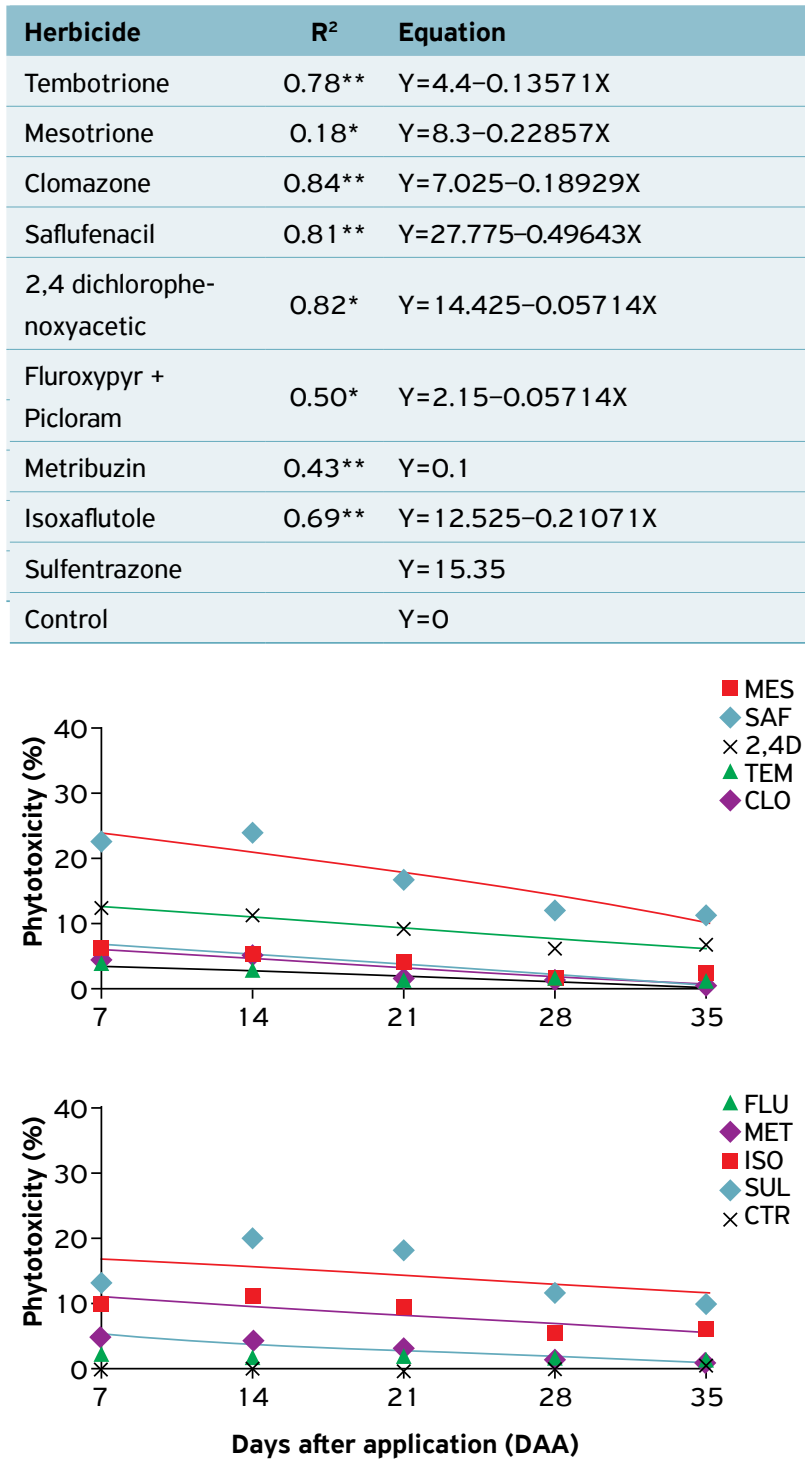

*significant at 5\% probability level; ${ }^{*}$ significant at $1 \%$ probability level by Tukey test

Figure 8. Phytotoxicity as a function of evaluation times in the cultivar RBO36153 under application of different herbicides, during the 18-month cultivation period.

ZENI NETO et al. (2008) found behavioral differences between the various clones tested in the analyzed environments. Therefore, the cultivars do not always behave similarly in different production environments, as occurs with the 12-month and 18-month cultivation periods.

When the herbicide 2,4 dichlorophenoxyacetic was applied, low phytotoxicity was found at 7 DAA, when there was phytotoxicity of $3 \%$, reducing to $1 \%$ at $35 \mathrm{DAA}$. This is probably due to anatomical structures existing in grasses like nodes, intercalary meristem, which enable the crop to reduce its absorption and translocation in the stem and leaves and metabolize the herbicide.

The other herbicide treatments caused in the sugarcane phytotoxicity below $6.7 \%$ in all evaluations, which demonstrates a high selectivity to the crop, enabling the management of broad-and narrow-leaf weeds in the case of mesotrione and tembotrione, but these are used to control weeds in early stages of development. In the case of the herbicides 2,4 dichlorophenoxyacetic and fluroxypyr + picloram, these are used to control broad-leaf plants in a more advanced stage of development and are selective to grasses in general, as their mechanism of action is auxin mimicking.

Similar data were reported by CARVALHO et al. (2010), who found that the treatment with mesotrione caused phytotoxicity of $4 \%$ at $15 \mathrm{DAA}$, which decreased to $1.8 \%$ at 30 DAA and injuries were no longer found in any herbicide treatment at 45 DAA. CORREIA; KRONKA (2010) found no phytotoxicity in the treatment with mesotrione at any time of evaluation, when it was used alone.

When the herbicide isoxaflutole was applied in the cultivar RB006995, at 7 DAA the phytotoxicity was equal to 33\% for the 18-month cultivation period and to approximately $1 \%$ for the 12-month cultivation period. For the cultivar RB036153 in the 18-month cultivation period, the herbicide isoxaflutole caused phytotoxicity of $11 \%$, much higher when compared to the 12-month cultivation period, when phytotoxicity was close to zero.

As observed for the 12-month cultivation period, SOARES et al. (2011) found that the highest levels of phytotoxicity were caused by the herbicide isoxaflutole, reducing the yield and technological quality of sugarcane.

The higher phytotoxicity caused by the herbicides isoxaflutole and sulfentrazone may be related to the fact that these herbicides are indicated for application in pre-emergence and early post-emergence in the sugarcane plant, which may have aggravated the symptoms of phytotoxicity, because they were applied at 30 days after sprouting.

Similarly, FERREIRA et al. (2012) found difference between the cultivars for the herbicide sulfentrazone, in which the cultivar RB925345 at 21 and 35 DAA showed phytotoxicity above $40 \%$, while RB867515 showed phytotoxicity of $20 \%$. BERTOLINO et al. (2014) found higher toxicity caused by the herbicides amicarbazone, isoxaflutole and diuron + hexazinone, but reduction in phytotoxicity from 45 DAA in sugarcane subjected to these herbicides.

SABBAG et al. (2017) do not restrict the use of saflufenacil in presprouted sugarcane seedlings when used alone without mixture with another herbicide.

COSTA et al. (2012) initially found more severe symptoms of injuries for the mixture of saflufenacil + Assist, followed by saflufenacil + Break Thru, at 3 and 7 DAA, whereas from 15 DAA the injuries began to decrease in treatments with saflufenacil in all cultivars.

\section{CONCLUSIONS}

The most phytotoxic herbicides for the 12-month cultivation period in the cultivars RB036153 and RB006995 were 
clomazone and sulfentrazone. For the 18-month cultivation period, the herbicides isoxaflutole, clomazone and sulfentrazone were the most phytotoxic, mainly for the cultivar RB006995. For most herbicides, there was reduction in phytotoxicity along the days after application. The most selective herbicides, which had low phytotoxicity and rapid detoxification in the crop for both cultivars and cultivation periods were tembotrione, mesotrione and fluroxypyr + picloram.

ACKNOWLEDGEMENTS: The authors thank and to UNIOESTE.

FUNDING: This study was financed in part by the Coordenação de Aperfeiçoamento de Pessoal de Nível Superior - Brasil (CAPES) Finance Code 001.

CONFLICTS OF INTEREST: The authors certify that they have no commercial or associative interest that represents a conflict of interest in connection with the manuscript.

ETHICAL APPROVAL: Not applicable.

AVAILABILITY OF DATA AND MATERIAL: The datasets generated and/or analyzed during the current study are available from the corresponding author on reasonable request.

AUTHORS' CONTRIBUTIONS: Conceptualization: Perego, I.; Duarte Júnior, J.B. Data curation: Perego, I.; Rosa, W.B.; Pratis, S.Q.B. Formal analysis: Perego, I.; Duarte Júnior, J.B.; Rosa, W.B.; Costa, A.C.T. Methodology: Perego, I.; Duarte Júnior, J.B.; Rosa, W.B.; Gonçalves Júnior, A.C. Project administration: Perego, I. Supervision: Perego, I.; Duarte Júnior, J.B. Validation: Perego, I.; Duarte Júnior, J.B.; Gonçalves Júnior, A.C. Visualization: Perego, I.; Duarte Júnior, J.B.; Rosa, W.B.; Pratis, S.Q.B.; Gonçalves Júnior, A.C.; Costa, A.C.T. Writing - original draft: Perego, I. Writing - review and editing: Perego, I.; Rosa, W.B.; Pratis, S.Q.B.

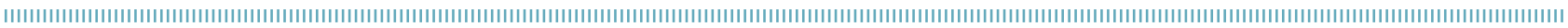
REFERENCES

ALVAREZ, R.; WUTKE, A.C.P.; ARRUDA, W.V.; RAIJ, B.V.; GOMES, A.C.; ZINK, F. Adubação da cana-de-acúcar: XIV. Adubação NPK em latossolo roxo. Bragantia, Campinas, v.50, n.2, p.359-374, 1991. https://doi.org/10.1590/ S0006-87051991000200014

BERTOLINO, C.B.; ALVES, P.L.C.A. Seletividade de herbicidas para cana-de-açúcar no sistema Plene em pré e pós-emergência. Revista Brasileira de Herbicidas, Londrina, v.13, n.2, p. 197-206, 2014. https://doi.org/10.7824/rbh.v13i3.249

CARVALHO, F.T.; CASTRO, R.M.; OTSUBO, R.I.; PEREIRA, F.A.R. Controle de dez espécies daninhas em cana-de-açúcar com o herbicida mesotrione em mistura com ametryn e metribuzin. Planta Daninha, Viçosa, v.28, n.3, p.585-590, 2010. https:// doi.org/10.1590/SO100-83582010000300015

CORREIA, N.M.; KRONKA JUNIOR, B. Eficácia de herbicidas aplicados nas épocas seca e úmida para o controle de Euphorbia heterophylla na cultura da cana-de-açúcar. Planta Daninha, Viçosa, v.28, n.4, p.853-863, 2010. https://doi.org/10.1590/ S0100-83582010000400019

COSTA, S.İ.A.; MARTINS, D.; CARDOSO, L.A.; RODRIGUES, A.C.P.; VITORINO, H.S.; MARQUES, R.P. Seletividade do herbicida saflufenacil aplicado em pós-emergência em dez variedades de cana-de-açúcar na condição de soca. Arquivos do Instituto Biológico, São Paulo, v.79, n.1, p.113-120, 2012. https://doi. org/10.1590/S1808-16572012000100017
FERREIRA, E.A.; SILVA, A.F.; SILVA, A.A.; SILVA, D.V.; GALON, L.L.; FRANÇA, A.C.; SANTOS, J.B. Toxidade de herbicidas a genótipos de cana-de-açúcar. Revista Trópica: Ciências Agrárias e Biológicas, Chapadinha, v.6, n.1, p.84-92, 2012. Available from: http://www. periodicoseletronicos.ufma.br/index.php/ccaatropica/article/ view/130. Access on: 23 Aug. 2018.

GALON, L.; FERREIRA, F.A.; SILVA, A.A.; CONCENÇO, G.; FERREIRA, E.A.; BARBOSA, M.H.P.; SILVA, A.F;; ASPIAZÚ, I.; FRANÇA, A.C.; TIRONI, S.P. Influência de herbicidas na atividade fotossintética de genótipos de cana-de-açúcar. Planta Daninha, Viçosa, v.28, n.3, p.591-597, 2009. https://doi.org/10.1590/S0100-83582010000300016

GALON, L.; SILVA, A.F.; ASPIAZÚ, I.; FERREIRA, E.A.; CONCENÇO, G.; TIRONI, S.P.; FERREIRA, F.A. Efeito de herbicidas nos componentes de rendimento de genótipos de cana-de-açúcar. Revista Brasileira de Herbicidas, Londrina, v.12, n.2, p.131-142, 2013. https:// doi.org/10.7824/rbh.v12i2.225

GIROTTO, M.; ARALDI, R.; VELINI, E.D.; JASPER, S.P.; GOMES, G.L.G.C.; CARBONARI, C.A. Eficiência fotossintética da cana-deaçúcar após a aplicação dos herbicidas S-metolachlor e atrazine em pós-emergência. Revista Brasileira de Herbicidas, Londrina, v.9, n.3, p.109-1 16, 2010. https://doi.org/10.7824/rbh.v9i3.84

SABBAG, R.S.; MONQUERO, P.A.; HIRATA, A.C.S.; SANTOS, P.H.V. Crescimento inicial de mudas pré brotadas de cana-de-açúcar submetidas a aplicação de herbicidas. Revista Brasileira de Herbicidas, Londrina, v.16, n.1, p.38-49, 2017. https://doi. org/10.7824/rbh.v16i1.481 
SANTOS, H.G.; JACOMINE, P.K.T.; ANJOS, L.H.C.; OLIVEIRA, V.A.; LUMBRERAS, J.F.; COELHO, M.R.; ALMEIDA, J.A.; ARAÚJO FILHO, J.C.; OLIVEIRA, J.B.; CUNHA, T.J.F. Sistema brasileiro de classificação de solos. Brasília: Embrapa, 2018. Available from: https://www.infoteca.cnptia.embrapa.br/infoteca/handle/ doc/1094003. Access on: 23 Aug. 2018.

SAS Institute Inc V World Programming Ltd: CA 21 Nov 2013. West Yorkshire: swarb.co.uk. 2013. Available from: https://swarb.co.uk/ sas-institute-inc-v-world-programming-Itd-ca-21-nov-2013/. Access on: 23 Aug. 2018.

SILVA, D.M.; AZANIA, C.A.M.; AZANIA, A.A.P.M.; BELUCI, L.R.; VITORINO, R.; GARCIA, J.C. Seletividade de herbicidas influenciada pelo estado nutricional da cana-de-açúcar. Revista Brasileira de Herbicidas, Londrina, v.12, n.1, p.56-67, 2013. https://doi. org/10.7824/rbh.v12i 1.209

SIMÕES, P.S.; CARBONARI, C.A.; NASCENTES, R.F.; STASIEVSKI, A.; VELINI, E.D. Selectivity of herbicides inhibitors of photosystem II for sugarcane cultivars. Planta Daninha, Viçosa, v.34, n.4, p.803-814, 2016 . https://doi.org/10.1590/ so $100-83582016340400021$

SINDICATO NACIONAL DA INDÚSTRIA DE PRODUTOS PARA A DEFESA VEGETAL (SINDIVEG). SINDIVEG e o setor de defensivos agrícolas. 2017. Available from: https://dados. contraosagrotoxicos.org/dataset/comercializacao-ibama-2017. Access on: 08 Aug. 2020.
SOARES, R.O.; AZANIA, C.A.M.; LORENZATO, C.M.; SCHIAVETTO, A.R; ZERA, F.S.; AZANIA, A.A.P.M. Herbicidas de diferentes mecanismos de ação e a seletividade a cultivares de cana-deaçúcar. Nucleus, Ituverava, v.8, n.1, p.337-350, 201 1. https:// doi.org/10.3738/1982.2278.487

SOUZA, J.R.; PERECIN, D.; AZANIA, C.A.M.; SCHIAVETTO, A.R.; PIZZO, I.V.; CANDIDO, L.S. Tolerância de cultivares de cana-de-açúcar a herbicidas aplicados em pós-emergência. Bragantia, Campinas, v.68, n.4, p.941-951, 2009. https://doi. org/10.1590/S0006-87052009000400014

TORRES, L.G.; FERREIRA, E.A.; ROCHA, P.R.R.; FARIA, A.T.; GONÇALVES, V.A.; GALON, L.; SILVA, A.F.; SILVA, A.A. Alterações nas características fisiológicas de cultivares de cana-de-açúcar submetida à aplicação de herbicidas. Planta Daninha, Viçosa, v.30, n.3, p.581-587, 2012 . https://doi.org/10.1590/ So $100-83582012000300014$

VELINI, E.D.; OSIPE, R.; GAZZIERO, D.L.P. (coord.). Procedimentos para instalação, avaliação e análise de experimentos com herbicidas. Londrina: SBCPD, 1995. 42p.

ZENI NETO, H.; OLIVEIRA, R.A.; DAROS, E.; BESPALHOK FILHO, J.C.; ZAMBON, J.L.C.; IDO, O.T.; WEBER, H. Seleção para produtividade, estabilidade e adaptabilidade de clones de cana-de-açúcar em três ambientes no estado do Paraná via modelos mistos. Scientia Agraria, Curitiba, v.9, n.4, p.425-430, 2008. https:// doi.org/10.5380/rsa.v9i4.12475 